\title{
Association between Helicobacter Pylori Infection and Iron Deficiency Anemia: A Cross Sectional Study
}

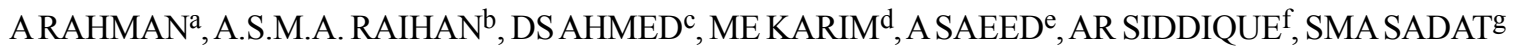

\begin{abstract}
Summary:
Background: Helicobacter pylori (H. pylori) remains one of the most common worldwide human infections and is associated with a number of important upper gastrointestinal (GI) conditions including chronic gastritis, peptic ulcer disease, gastric carcinoma and special type of lymphoma. Anaemia is a common disorder in developing countries and the commonest cause is iron deficiency. There are many causes for high prevalence of this disorder in our society, many are well-known and investigated while some are new and not well established. Although $\mathrm{H}$. pylori associates peptic ulcers and gastric malignancy can cause bleeding, resulting in iron deficiency, but majority of patients infected with $\mathrm{H}$. pylori does not have ulcer or malignancy. They usually have chronic gastritis that is not associated with GI bleeding. About 35\% of iron deficiency anaemia cases remain unexplained after a gastrointestinal evaluation. Recently investigation focused on the role of $\mathrm{H}$. pylori, in the development of extra-gastrointestinal diseases including Iron deficiency anaemia.
\end{abstract}

Methodology: This observational, cross sectional study was carried out at BSMMU, Dhaka from July 2010 to October 2011 to find out the association between $\mathrm{H}$. pylori infection and iron deficiency anemia in Bangladeshi adults. Patients with dyspepsia and indication of upper GI endoscopy were

a. Dr. Anisur Rahman, MBBS, MD (Gastroenterology), Assistant Professor, Dept. of Gastroenterology, Sher-EBangla Medical College, Barishal.

b. Dr. A.S.M.A. Raihan, MBBS, MD, FRCP. Ex-Chairman and Professor, Dept. of Gastroenterology, BSMMU.

c. Dr. Dewan Saifuddin Ahmed, MBBS, FCPS, MD. Professor, Dept. of Gastroenterology, BSMMU.

d. Dr. Mohammad Enamul Karim, MBBS, FCPS, MD. Assistant Professor, Dept. of Gastroenterology, Sheikh Rasel National Gastro liver Institute and Hospital.

e. Dr. Atia Saeed, MBBS, FCPS. MD. Assistant Professor, Dept. of Gastroenterology, Anwar Khan Modern Medical College Hospital.

f. Dr. Abu Raihan Siddique, MBBS, MD, MRCP. Assistant Professor, Dept. of Gastroenterology, Sheikh Sayera Khatun Medical College, Gopalgonj.

g. Dr. S. M. Anwar Sadat, BDS, MCPS, FCPS, MS (OMS), Associate Professor, Dept. of Oral and Maxillofacial Surgery, Dhaka Dental College.

Address of Correspondence: Dr. Anisur Rahman, Assistant Professor, Dept. of Gastroenterology, Sher-E- Bangla Medical College, Barisal. Eastern Karim, 2/5 Shahjahan Road, Mohammadpur, Dhaka 1207. Mobile: +8801913373846 , Email: dranismd2012@yahoo.com

Received: 1 April 2019

Accepted: 10 February 2020 initially enrolled in the study and finally a total of 168 subjects were included based on inclusion and exclusion criteria.

Result: Among 168 patients, 105 (62.5\%) were male and 63(37.5\%) were female with the mean age of 33.25 years. On endoscopy, 147(87.5\%) of the patients had normal findings and 21(12.5\%) had erosive gastritis. None of them had hemorrhagic erosive gastritis. Among 168 patients, $115(68.45 \%)$ were positive and $53(31.55 \%)$ were negative for H. pylori by rapid urease test.

In our study, we have found a significant low mean serum ferritin level $(P<0.001)$ in $\mathrm{H}$. pylori infected patients. This result is consistent with most of previous data concerning the effect of $\mathrm{H}$. pylori infection on iron metabolism. This study has also revealed a significant $(P<0.001)$ lower value of mean $\mathrm{MCV}$ and $\mathrm{MCH}$ in $\mathrm{H}$. pylori positive patients. Regarding hemoglobin value, our study has showed no significant $(P>0.05)$ different in hemoglobin level according to H. pylori status.

Conclusion: Though there was no significant low hemoglobin level in our study, mean hemoglobin level was low in H. pylori positive patient. In our study H. pylori was not significantly associated with iron deficiency anemia but it was significantly associated with iron deficiency.

Key words: Helicobacter pyloin (HP), iron deficiency anaemia (IDA), Proton pump inhibitor (PPI).

(J Bangladesh Coll Phys Surg 2020; 38: 68-78)

DOI: https://doi.org/10.3329/jbcps.v38i2.45630

Introduction:

Helicobacter pylori (H. pylori) remains one of the most common worldwide human infections and is associated with a number of important upper gastrointestinal (GI) conditions including chronic gastritis, peptic ulcer disease, gastric carcinoma and special type of lymphoma. The prevalence of $H$. pylori is closely tied to socioeconomic conditions and accordingly, this infection is more common in developing countries than in developed countries. ${ }^{1}$ In developing countries, $70 \%$ to $90 \%$ of the population carries $H$. pylori, almost all of these acquire the infection before the age of 10 years. $^{2}$ In developed countries, the prevalence of infection is lower, ranging from $25 \%$ to $50 \%$. The data from developed countries also suggest that most infections are acquired in childhood. ${ }^{2}$ 
The prevalence of $H$. pylori infection is very high in Bangladesh. A study conducted on Bangladeshi children by ICDDRB scientists have shown that, $60 \%$ are infected by the age of three months and $80 \%$ are infected by three years of age. ${ }^{3}$ In another study, carried out on adult male by Ahmed et al. about $92 \%$ have been found to be seropositive for $H$. pylori antibody. ${ }^{4}$

Helicobacter pylori is a gram-negative, micro-aerophilic curved bacterium which persistently colonizes the human stomach because of its capacity to establish close contact with the gastric mucosal cells. ${ }^{5}$ It is an obligate parasite, specific for primates, including humans ${ }^{6}$. Helicobacter pylori colonizes almost half of world's population ${ }^{7}$ and amongst these only a minority of them develop associated clinical disease. ${ }^{8}$

The infection is typically acquired in childhood and has a long latent period. ${ }^{6}$ In most patients, it does not cause symptoms and the infection often persists without any clinically evident disease. However, only $10-20 \%$ of infected patients develop severe diseases during their lifetime. ${ }^{7}$ In fact, according to some epidemiological studies it is a class 1 carcinogen for gastric adenocarcinoma. ${ }^{9}$ It is the most common proven risk factor for human gastric cancer (those not arising from cardiac end of the stomach). ${ }^{4,10}$

The virulence factors for $H$. pylori include cagA, vacA, urease, and outer membrane proteins including babA, sabA, oipA, alpA as well as iceA. ${ }^{11}$ It is proposed that the clinical outcome of $H$. pylori infection is linked to certain strains expressing vacA and cag $\mathrm{A}^{12,13,14,15 \text {, and }}$ these factors have been extensively studied.

Recent studies suggest that in most patients Chronic gastritis (CG) is a bacterial (microbial) disease, and that a successful treatment of the infection results in improvement of gastritis. ${ }^{16}$ This has important therapeutic implications, particularly with respect to peptic ulcer disease.

Numerous studies are being carried out for extra-gastric manifestations of $H$. pylori infection including cardiovascular, hematological, neurological and hepatobilliary diseases. ${ }^{17,18}$ The Maastricht III consensus report, 2005 recommended that presence of $H$. pylori infection should be sought for and treated in unexplained iron deficiency anemia and ITP. ${ }^{15}$

Anemia is a common disorder in developing countries and the commonest cause is iron deficiency ${ }^{19-21}$.
According to WHO, anemia is estimated to affect more than 2 billion people worldwide. Half of all reason for anemia is iron deficiency ${ }^{22}$. There are many causes for high prevalence of this disorder in our society, many are well-known and investigated while some are new and not well established. Although $H$. pylori associates peptic ulcers and gastric malignancy can cause bleeding, resulting in iron deficiency, but majority of patients infected with $H$. pylori does not have ulcer or malignancy. They usually have chronic gastritis, that is not associated with GI bleeding ${ }^{23}$. About $35 \%$ of iron deficiency anemia cases remain unexplained after a gastrointestinal evaluation ${ }^{24}$. Recently investigation focused on the role of $H$. pylori, in the development of extra-gastrointestinal diseases including Iron deficiency anemia.

Recently several sero epidemiologic studies have suggested a link between iron deficiency anemia and $H$. pylori infection. ${ }^{25,26}$ Epidemiological studies have shown that persons seropositive for $H$. pylori infection have a significantly lower s. ferritin level. ${ }^{27,28}$ In a Danish population based study, persons who were seropositive for $H$. pylori infection had a $40 \%$ increased risk of having a reduced serum ferritin level as compared with seronegative individuals. ${ }^{23}$ However, a few epidemiologic studies do not support an association between $H$. pylori infection and iron deficiency anemia. Collett et al. found no significant differences in serum ferritin levels between $H$. pylori seropositive or seronegative males or females in a study of 1060 adults in New Zealand. ${ }^{29}$ Further studies are required to confirm a causal relationship and explore mechanisms of disease. In Bangladesh, no study has been carried out to find the association between $H$. pylori infection and iron deficiency anemia in adult.

Possible pathogenic mechanisms for iron deficiency anemia (IDA) in H. pylori infected patient are bleeding from PUD or gastric malignancy, Occult blood loss secondary to chronic erosive gastritis, increased iron uptake and utilization by $H$. pylori bacteria and decreased iron absorption secondary to chronic gastritis and hypo or achlorhydria. Most dietary iron is in the non-haemic ferric form, and an acidic intragastric $\mathrm{P}^{\mathrm{H}}$ is needed to reduce it to the ferrous form for absorption. This reaction is promoted by gastric acidity and ascorbic acid (AA), which is thus considered the most potent regulator of iron absorption. ${ }^{30}$ Patients with $H$. pylori 
gastritis showed an increased in intra gastric $\mathrm{P}^{\mathrm{H}}$ with a median of $>3$, a $\mathrm{P}^{\mathrm{H}}$ that is known to be critical in the process of iron absorption. Moreover, ascorbic acid is actively secreted from plasma to the gastric juice, ${ }^{31}$ but the concentration of ascorbic acid in the gastric juice of patients with $H$. pylori gastritis and IDA is clearly reduced in comparison with both healthy and nonanemic H. pylori controls. ${ }^{32-34}$

The level of ferritin in serum reflects the magnitude of the mobilizable iron stores in the body ${ }^{35}$ and is a sensitive marker for iron status. Hemoglobin levels are maintained with in normal range until the body iron stores are exhausted. ${ }^{23}$ Thus hemoglobin levels could be within normal ranges with very low or absent iron stores. ${ }^{23,36}$

H. pylori may have a protective role in Barrett's esophagus, and esophageal adenocarcinoma, as an inverse association have been observed between the presence of it (especially cagA positive strains) and these disorders. ${ }^{37}$ The absence of $H$. pylori is associated with an increased risk of allergies and childhood onset asthma. ${ }^{38}$ Multiple studies have revealed that it may also be involved in physiologic regulation of leptin and ghrelin the multifunctional hormones that help to regulate the body weight. ${ }^{39}$

The status of iron was defined as:

Adequate iron stores: ferritin $>30 \mu \mathrm{g} / \mathrm{L}$,

low iron stores: ferritin $15-30 \mu \mathrm{g} / \mathrm{L}$,

depleted iron stores: ferritin $<15 \mu \mathrm{g} / \mathrm{L}$,

iron deficiency anaemia males: ferritin $<15 \mu \mathrm{g} / \mathrm{L}+$ haemoglobin $<13.0 \mathrm{~g} / \mathrm{dl}$ and

iron deficiency anaemia females: ferritin $<15 \mu \mathrm{g} / \mathrm{L}+$ haemoglobin $<11.50 \mathrm{~g} / \mathrm{dl}$

\section{Objectives:}

To find out the association between $H$. pylori infection and iron deficiency anemia.

Specific objectives: 1 . To see any significant change in blood iron parameters in $H$. pylori positive patients and to compare blood iron parameters between $H$. pylori positive and $H$. pylori negative patients.

Materials and Methods:

Type of study: An observational, cross sectional study.

Place of study: Department of Gastroenterology, Biochemistry, Clinical pathology of
BSMMU, Dhaka, Bangladesh.

Period of study: From July 2010 to October 2011.

Study population: Patients attending the Department of Gastroenterology for dyspeptic symptoms like upper abdominal pain or discomfort, anorexia, nausea, vomiting, bloating, belching, early satiety etc were initially enrolled for the study. Patients who were found to be normal or found to have endoscopic atrophic gastritis or erosive gastritis were finally included for the study. Informed written consents were obtained from the all patients.

Sample size: Minimum sample size was calculated at 5\% level of significance and $95 \%$ confidence level. According to this formula, the minimum sample size was 384. But due to time constraint sample size was compromised. However, one hundred and sixty eight patients based on inclusion and exclusion was included in the study.

Ethical clearance was obtained from ethical review committee of BSMMU

\section{Inclusion criteria:}

1. Patients having indication for upper GIT endoscopy.

2. Age: $18-60$ years.

3. Ambulatory patients of both sexes.

4. Patients willing to undergo upper GI endoscopy and biopsy.

\section{Exclusion criteria:}

1. Patients having peptic ulcers, erosive hemorrhagic gastritis, gastric malignancy and varices.

2. Patients having menorrhagia, upper or lower GI bleeding, or recent blood donation.

3. Patients with obvious feature of malabsorption.

4. Patients having Intestinal worm infestation.

5. Pregnancy and Lactation.

6. Concomitant other severe systemic diseases.

7. Regular user of NSAIDS.

8. Diagnosed case of hematological disease.

9. Unwilling or contraindication for upper GI endoscopy.

10. Cases with false positive RUT 


\section{Methods:}

Patients attending the department of gastroenterology with dyspepsia and indication for upper GI endoscopy were initially enrolled based on the above mentioned inclusion and exclusion criteria. Their clinical history and physical findings were noted in the standard data sheet. Patients who received proton pump inhibitors, antibiotics or bismuth compounds were advised to come for endoscopy after stopping the above mentioned drugs for at least two weeks. After proper explanation written informed consent were obtained from the selected patients for upper GI endoscopy and biopsy. Patients underwent endoscopy in the department of Gastroenterology, BSMMU in presence of an experienced endoscopist using an Olympus forward viewing video endoscope under topical lignocaine anesthesia. Patients who were found to be normal or found to have endoscopic atrophic gastritis or erosive gastritis were finally included for the study During endoscopy two biopsy samples were taken, one from the body and another from the antrum of the stomach. Rapid urease test (CLO) of biopsy specimens for detection of $H$. pylori was done immediately and was observed for up to 24 hours to see the color change of test medium from straw to pink or reddish. Patients who tested positive for $H$. pylori were placed under group A wing and those who tested negative for $H$. pylori were placed under group B wing. Different variables (e.g age, sex, symptoms etc) and means of iron parameters $(\mathrm{Hb}$, S. ferritin, MCV, MCH) of two groups were compared. Prior to the procedure endoscope and biopsy forceps were disinfected by immersing in the gluteraldehyde solution $2 \%\left(\mathrm{CIDEX}^{\mathrm{R}}\right)$ for 10 minutes. Side channels were rinsed with normal saline. All patients underwent $\mathrm{CBC}$, S. Ferritin estimation and Stool R/M/E for detection of ova in stool.

A gel matrix media embedded with urea and a $\mathrm{pH}$ sensitive indicator was used for the rapid urease test (RUTs).

\section{Results:}

A total of 168 patients were finally included for the study. Among them 115 patients were RUT positive for $H$. pylori and 53 patients were RUT negative for $H$. pylori. H. pylori positive patients were placed in group A and H. pylori negative patients were placed in group B.

A total of 168 patients were finally included in this study. They were divided into five groups according to age. Majority of the patients were found in the age group of 21-30 years, which was 51(44.3\%) in Group A and $24(45.3 \%)$ patients in Group B. The mean age was found $34.1 \pm 11.8$ years in Group A and $32.5 \pm 8.1$ years in Group B. The value of unpaired t-test was 0.372 and it was not statistically significant $(p>0.05)$. (Table I)

\section{Table-I}

Age distribution of the study patients $(n=168)$.

\begin{tabular}{|c|c|c|c|c|c|}
\hline \multirow[t]{2}{*}{ Age (in year) } & \multicolumn{2}{|c|}{ Group A $(n=115)$} & \multicolumn{2}{|c|}{ Group B $(n=53)$} & \multirow[t]{2}{*}{ PValue } \\
\hline & $\mathrm{n}$ & $\%$ & $\mathrm{n}$ & $\%$ & \\
\hline$\leq 20$ & 9 & 7.8 & 2 & 3.8 & \\
\hline $21-30$ & 51 & 44.3 & 24 & 45.3 & \\
\hline $31-40$ & 27 & 23.5 & 20 & 37.7 & \\
\hline $41-50$ & 14 & 12.2 & 6 & 11.3 & \\
\hline $51-60$ & 14 & 12.2 & 1 & 1.9 & \\
\hline Mean \pm SD & \multicolumn{2}{|c|}{$34.1 \pm 11.8$} & \multicolumn{2}{|c|}{$32.5 \pm 8.1$} & $0.372^{\text {ns }}$ \\
\hline Range (min-max) & \multicolumn{2}{|c|}{$(18-60)$} & \multicolumn{2}{|c|}{$(19-52)$} & \\
\hline
\end{tabular}

Group $\mathrm{A}=$ Positive for $H$. pylori, Group $\mathrm{B}=\mathrm{Negative}$ for $H$. pylori, NS=Not significant

$\mathrm{P}$ value reached from unpaired t-test. 


\section{Gender distribution of study patients $(\mathrm{n}=168)$.}

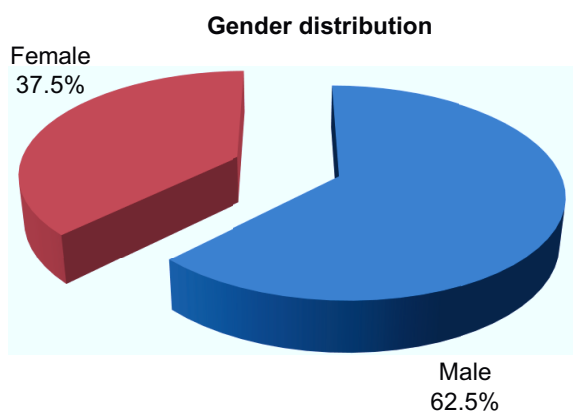

Fig.-I: Pie chart showing male and female proportion in the study patients $(n=168)$.

Table-II

Clinical feature of the study patients $(n=168)$

\begin{tabular}{|c|c|c|c|c|c|}
\hline \multirow[t]{2}{*}{ Age (in year) } & \multicolumn{2}{|c|}{ Group $A(n=115)$} & \multicolumn{2}{|c|}{ Group B $(\mathrm{n}=53)$} & \multirow[t]{2}{*}{ P Value } \\
\hline & $\mathrm{n}$ & $\%$ & $\mathrm{n}$ & $\%$ & \\
\hline Upper abdominal pain & 92 & 80.0 & 28 & 52.8 & $0.001^{\mathrm{s}}$ \\
\hline Anorexia & 47 & 40.9 & 10 & 18.9 & $0.005^{\mathrm{s}}$ \\
\hline Belching & 27 & 23.5 & 22 & 41.5 & $0.016^{\mathrm{s}}$ \\
\hline Abdominal discomfort & 30 & 26.1 & 20 & 37.7 & $0.124^{\mathrm{ns}}$ \\
\hline Burning sensation of abdomen & 57 & 49.6 & 32 & 60.4 & $0.191^{\mathrm{ns}}$ \\
\hline Nausea & 59 & 51.3 & 26 & 49.1 & $0.786^{\mathrm{ns}}$ \\
\hline Vomiting & 21 & 18.3 & 4 & 7.5 & $0.069^{\text {ns }}$ \\
\hline Bloating & 87 & 75.7 & 34 & 64.2 & $0.122^{\mathrm{ns}}$ \\
\hline Early satiety & 41 & 35.7 & 14 & 26.4 & $0.235^{\mathrm{ns}}$ \\
\hline
\end{tabular}

Table-III

Endoscopic diagnosis of the study patients $(n=168)$.

Endoscopic diagnosis

$\operatorname{Group} A(n=115)$

\begin{tabular}{cc}
\hline $\mathrm{n}$ & $\%$ \\
100 & 87.0
\end{tabular}

Erosive gastritis

15

13.0

This study finally involved 168 patients. Among them 105 patients $(62.5 \%)$ were male and 63 patients $(37.5 \%)$ were female. (Figure I)

The above table IV shown the clinical feature of the study patients. Maximum patients had abdominal pain in group A, which was $92(80.0 \%)$, however in group B, most of the patients had bloating, which was 34(64.2). Upper abdominal pain, anorexia and belching were statistically significant $(\mathrm{p}<0.05)$ but abdominal

\begin{tabular}{cccc}
\multicolumn{2}{c}{ Group B $(\mathrm{n}=53)$} & & PValue \\
\cline { 1 - 2 } $\mathrm{n}$ & $\%$ & \\
\hline 47 & 88.7 & $0.754^{\mathrm{ns}}$ \\
6 & 11.3 & \\
\hline
\end{tabular}
discomfort, burning sensation of abdomen, nausea, bloating, and early satiety was not significant $(p>0.05)$ between two groups in chi square test.

The above table $\mathrm{V}$ shown the endoscopic diagnosis of the study patients. Normal finding was found $100(87.0 \%)$ in group A and 47(88.7\%) in group B. Erosive gastritis was found $15(13.0 \%)$ and $6(11.3 \%)$ in group A and group B respectively. The difference was not statistically significant $(p>0.05)$ between two groups in Chi square test. 
H. pylori status of the study patients $(\mathrm{n}=168)$.

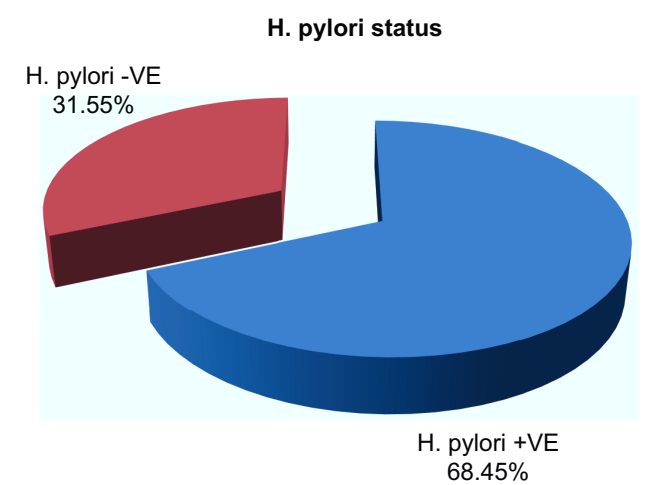

Fig.-IV: Pie chart showing H. pylori status of the study patients ( $n=168)$.

Table-IV

Mean serum ferritin of the study patients ( $n=168)$.

\begin{tabular}{|c|c|c|c|c|c|}
\hline \multirow[t]{2}{*}{ S. ferritin $(\mathrm{mg} / \mathrm{L})$} & \multicolumn{2}{|c|}{ Group $A(n=115)$} & \multicolumn{2}{|c|}{ Group B (n=53) } & \multirow[t]{2}{*}{ PValue } \\
\hline & $\mathrm{n}$ & $\%$ & $\mathrm{n}$ & $\%$ & \\
\hline$>30 \mathrm{mg} / \mathrm{L}$ & 78 & 67.8 & 51 & 96.2 & \\
\hline $15-30 \mathrm{mg} / \mathrm{L}$ & 21 & 18.3 & 2 & 3.8 & \\
\hline$<15 \mathrm{mg} / \mathrm{L}$ & 14 & 12.2 & 0 & 0.0 & \\
\hline Mean \pm SD & \multicolumn{2}{|c|}{$64.6 \pm 61.6$} & \multicolumn{2}{|c|}{$120.5 \pm 77.9$} & $0.001^{\mathrm{s}}$ \\
\hline Range (min-max) & \multicolumn{2}{|c|}{$(0.01-402.8)$} & \multicolumn{2}{|c|}{$(25-370.2)$} & \\
\hline
\end{tabular}

$\mathrm{P}$ value reached from unpaired t-test.

Table-V

Association between H. pylori infection and log transformed serum ferritin levels in multiple linear regression model.

Adjusted for age and sex

H pylori infection

Not infected

Infected
Geometric mean of S. ferritin level

$53 \quad 99.1$

$115 \quad 39.9$

Adjusted for multiple covariates*

\begin{tabular}{cc}
$\%$ change $(95 \% \mathrm{CI})$ & $\%$ change $(95 \% \mathrm{CI})$ \\
Reference & Reference \\
$-28.3 \%(-4.83$ to- 8.4$)$ & $-29.0 \%(-4.9$ to -9.0$)$ \\
\hline
\end{tabular}

* Adjusted for sex, age, residence, profession, income and family member

This study was finally involved 168 patients. Among them 115 patients $(68.45 \%)$ were CLO positive for $H$. pylori and 53 patients (31.55\%) were CLO negative for H. pylori. (Figure IV)

The above table VI shown the S. ferritin of the study patients. Maximum S. ferritin level was found $>30 \mathrm{mg} / \mathrm{L}$ in both groups, which was $78(67.8 \%)$ in group A and $51(96.2 \%)$ in group B. S. ferritin level 15 - $30 \mathrm{~g} / \mathrm{L}$ was found 21(18.3\%) in group A and 2(3.8\%) in group B. S. ferritin level $<15 \mathrm{mg} / \mathrm{L}$ was found $14(12.2 \%)$ in group A but not found in group B. The mean S. ferritin was found $64.6 \pm 61.6 \mathrm{mg} / \mathrm{L}$ with range from 0.01 to $402.8 \mathrm{mg} /$ L in group A and $120.5 \pm 77.9 \mathrm{mg} / \mathrm{L}$ with range from 25 to $370.2 \mathrm{mg} / \mathrm{L}$ in group B. The mean difference was statistically significant $(p<0.05)$ between two groups in unpaired t-test. 
Table-VI

Mean MCV of the study patients ( $n=168)$.

\begin{tabular}{|c|c|c|c|c|c|}
\hline & \multicolumn{2}{|c|}{ Group $A(n=115)$} & \multicolumn{2}{|c|}{ Group B $(n=53)$} & \multirow[t]{2}{*}{ P Value } \\
\hline & Mean & $\pm \mathrm{SD}$ & Mean & $\pm \mathrm{SD}$ & \\
\hline$\overline{\mathrm{MCV} \text { (in fL) }}$ & 85.4 & \pm 6.9 & 89.3 & \pm 3.9 & $0.001^{\mathrm{s}}$ \\
\hline Range (min-max) & $(56$ & $-103)$ & $(82$ & $-98)$ & \\
\hline
\end{tabular}

$P$ value reached from unpaired t-test.

Table-VII

Mean MCH of the study patients $(n=168)$

\begin{tabular}{lcccccc} 
& \multicolumn{2}{c}{ Group A $(\mathrm{n}=115)$} & & \multicolumn{2}{c}{ Group B $(\mathrm{n}=53)$} & \multicolumn{2}{c}{ P Value } \\
\cline { 2 - 3 } \cline { 5 - 6 } & Mean & & & Mean & \pm SD & \\
\hline MCH (in pg) & 27.5 & & & 29.0 & \pm 1.2 & $0.001^{\mathrm{s}}$ \\
Range (min-max) & $(19$ & $-32)$ & & $(26$ & $-31)$ & \\
\hline
\end{tabular}

$P$ value reached from unpaired t-test.

Table-VIII

$H b$ of the study patients according to male and female $(n=168)$

\begin{tabular}{|c|c|c|c|c|c|}
\hline \multirow[t]{2}{*}{$\mathrm{Hb}(\mathrm{gm} / \mathrm{dl})$} & \multicolumn{2}{|c|}{ Group A $(n=115)$} & \multicolumn{2}{|c|}{ Group B $(n=53)$} & \multirow[t]{2}{*}{ P Value } \\
\hline & $\mathrm{n}$ & $\%$ & $\mathrm{n}$ & $\%$ & \\
\hline$\overline{\text { Male }}$ & \multicolumn{2}{|c|}{$(n=62)$} & \multicolumn{2}{|c|}{$(n=43)$} & \\
\hline$\geq 13$ (normal) gm/dl & 51 & 82.3 & 38 & 88.4 & \\
\hline$<13$ (Low) gm/dl & 11 & 17.7 & 5 & 11.6 & \\
\hline Mean \pm SD & 13.9 & \pm 1.2 & 14.3 & \pm 0.8 & $0.059^{\text {ns }}$ \\
\hline Range (min-max) & $(9.3$ & $-16.2)$ & $(12.6$ & $-15.8)$ & \\
\hline Female & $(n=53)$ & $(n=10)$ & & & \\
\hline eH11.5 (normal) gm/dl & 38 & 71.7 & 9 & 90.0 & \\
\hline$<11.5$ (Low) gm/dl & 15 & 28.3 & 1 & 10.0 & \\
\hline Mean \pm SD & 12.0 & \pm 1.1 & 12.6 & \pm 1.0 & $0.114^{\mathrm{ns}}$ \\
\hline Range (min-max) & $(9.0$ & $-14.3)$ & $(10.6$ & $-14.1)$ & \\
\hline
\end{tabular}

$\mathrm{P}$ value reached from unpaired t-test.

The percentage of change in serum ferritin concentration according to the presence of the infection was calculated by $\exp (b)$, where $b$ is the corresponding regression coefficient.

The above table VII presents the results of linear regression models. The log transformation of serum ferritin concentration was necessary due to highly skewed distribution. The log transformation values serum ferritin concentration were close to normally distributed. Age and sex adjusted geometric mean of $\mathrm{S}$. ferritin concentration was $99.1 \mu \mathrm{g} / \mathrm{L}$ for noninfected and $39.9 \mu \mathrm{g} / \mathrm{L}$ for $H$. pylori infected persons. In the multiple regression model $H$. pylori infection was associated with a $29.0 \%$ decrease in serum ferritin $(95 \% \mathrm{CI}=4.9$ to -9.0$\left.) ; \mathrm{r}^{2}=0.26\right)$.

The above table VIII shown the MCV of the study patients. The mean MCV was found $85.4 \pm 6.9 \mathrm{fL}$ with range from 56 to $103 \mathrm{fL}$ in group A and $89.3 \pm 3.9 \mathrm{fL}$ with range from 82 to $98 \mathrm{fL}$ in group $\mathrm{B}$. The mean difference was statistically significant $(p<0.05)$ between two groups in unpaired t-test.

The above table IX shown the MCH of the study patients. The mean $\mathrm{MCH}$ was found $27.5 \pm 2.4 \mathrm{pg}$ with 
Table-IX

Iron deficiency Anaemia status according to Hb and Serum ferritin level of the study patients ( $n=168)$.

\begin{tabular}{|c|c|c|c|c|c|}
\hline \multirow{3}{*}{$\begin{array}{l}\text { Iron deficiency Anaemia } \\
\text { Male }\end{array}$} & \multicolumn{2}{|c|}{ Group $A(n=115)$} & \multicolumn{2}{|c|}{ Group B(n=53) } & \multirow[t]{3}{*}{$P$ value } \\
\hline & $\mathrm{n}$ & $\%$ & $\mathrm{n}$ & $\%$ & \\
\hline & \multicolumn{2}{|c|}{$(\mathrm{n}=62)$} & \multicolumn{2}{|c|}{$(\mathrm{n}=43)$} & \\
\hline Iron deficiency anaemia & 2 & 3.2 & 0 & 0.0 & $0.346^{\mathrm{ns}}$ \\
\hline No iron deficiency anaemia & 60 & 96.8 & 43 & 100.0 & \\
\hline Female & $(n=53)$ & $(\mathrm{n}=10)$ & & & \\
\hline Iron deficiency anaemia & 7 & 13.2 & 0 & 0.0 & $0.278^{\mathrm{ns}}$ \\
\hline No iron deficiency anaemia & 46 & 86.8 & 10 & 100.0 & \\
\hline
\end{tabular}

Iron deficiency anaemia:

Male: $\mathrm{Hb}<13 \mathrm{gm} / \mathrm{dl}$ and S. ferritin $<15 \mu \mathrm{g} / \mathrm{L}$

Female: $\mathrm{Hb}<11.5 \mathrm{gm} / \mathrm{dl}$ and $\mathrm{S}$. ferritin $<15 \mu \mathrm{g} / \mathrm{L}$

$\mathrm{P}$ value reached from chi square test.

Table-X

Frequency of iron deficiency, iron deficiency anemia according to H. pylori status.

\begin{tabular}{|c|c|c|c|c|c|c|}
\hline & \multicolumn{6}{|c|}{ Hemoglobin } \\
\hline & \multicolumn{3}{|c|}{$\begin{array}{c}\text { Low Hb } \\
\text { Depleted iron stores }\end{array}$} & \multicolumn{3}{|c|}{$\begin{array}{c}\text { Normal } \mathrm{Hb} \\
\text { Low iron stores }\end{array}$} \\
\hline & $\begin{array}{c}\text { Depleted } \\
\text { iron stores } \\
\mathrm{n} \\
\end{array}$ & $\begin{array}{c}\text { Low iron stores } \\
\text { iron stores } \\
\mathrm{N} \\
\end{array}$ & $\begin{array}{c}\text { Adequate } \\
\text { iron stores } \\
n \\
\end{array}$ & $\begin{array}{c}\text { Depleted } \\
\text { iron stores } \\
\mathrm{N} \\
\end{array}$ & $\begin{array}{c}\text { Low } \\
\text { iron stores } \\
\mathrm{N} \\
\end{array}$ & $\begin{array}{c}\text { Adequate } \\
\text { iron stores } \\
\mathrm{N} \\
\end{array}$ \\
\hline \multicolumn{7}{|l|}{ Male } \\
\hline Group A & 2 & 0 & 8 & 2 & 10 & 40 \\
\hline Group B & 0 & 0 & 5 & 0 & 2 & 36 \\
\hline \multicolumn{7}{|l|}{ Female } \\
\hline Group A & 7 & 1 & 7 & 5 & 10 & 23 \\
\hline Group B & 0 & 0 & 1 & 0 & 0 & 9 \\
\hline \multicolumn{7}{|l|}{ Total } \\
\hline Group A & 9 & 1 & 15 & 7 & 20 & 63 \\
\hline Group B & 0 & 0 & 6 & 0 & 2 & 45 \\
\hline
\end{tabular}

range from 19 to $32 \mathrm{pg}$ in group A and $29 \pm 1.2 \mathrm{pg}$ with range from 26 to $31 \mathrm{pg}$ in group $\mathrm{B}$. The mean difference was statistically significant $(p<0.05)$ between two groups in unpaired t-test.

The above table $\mathrm{X}$ shown the $\mathrm{Hb}$ of the study patients according to male and female patients. Among the male, $\mathrm{Hb}$ level e"13 (normal) gm/dl was found $38(82.3 \%$ ) in group A and 38(88.4\%) in group B. Hb level $<13$ (Low) $\mathrm{gm} / \mathrm{dl}$ was found $11(17.7 \%)$ and $5(11.6 \%)$ in group A and group $\mathrm{B}$ respectively in male patients. The mean $\mathrm{Hb}$ level was $13.9 \pm 1.2 \mathrm{gm} / \mathrm{dl}$ in group $A$ and $14.3 \pm 0.8$ in group $\mathrm{B}$ in male patients. Among the female patients, Hb level was e"11.5 (normal) gm/dl found 38(71.7\%) in group A and $9(90.0 \%$ ) in group B. Hb level was $<11.5$ (Low) gm/ $\mathrm{dl}$ found $15(28.3 \%)$ and $1(10.0 \%)$ in group $\mathrm{A}$ and group $\mathrm{B}$ respectively in female patients. The mean $\mathrm{Hb}$ level was $12.0 \pm 1.1 \mathrm{gm} / \mathrm{dl}$ in group A and $12.6 \pm 1.0$ in group B in female patients. The mean difference was not statistically significant $(p>0.05)$ between two groups of both male and female in unpaired t-test.

The above table XI showed the iron deficiency anaemia status according to $\mathrm{Hb}$ and $\mathrm{S}$. ferritin level of the study patients. In male patients, iron deficiency anaemia was found 2(3.2\%) in group A and not found in group B. In the female patients, it was found $7(3.2 \%)$ in group $A$ and not found in group $B$. The difference was not statistically 
significant $(p>0.05)$ between the two groups in chi square test. Other results are depicted in the table XI.

Frequency of iron deficiency anemia was 9 and low iron stores 1 in low hemoglobin level in group A but not found in group B. Frequency of depleted iron stores was 7 and low iron stores 20 in normal hemoglobin level in group A. In group B with normal hemoglobin level, depleted iron stores was not found but low iron stores found in 2 patients.(Table XII)

\section{Discussion:}

Anemia is a common disorder in the developing countries and the commonest cause is iron deficiency. ${ }^{19-}$

21 there are many causes for the high prevalence of this disorder in our society, many are well-known and investigated while some are new and not well established. Although H. pylori associated peptic ulcers and gastric malignancies can cause bleeding, resulting in iron deficiency, but majority of patients infected with $H$. pylori does not have ulcer or malignancy. They usually have chronic gastritis which is not associated with GI bleeding. ${ }^{23}$ However in many cases despite thorough investigations causes of IDA remain unexplained. Recently investigations are more focused on the role of $\mathrm{H}$. pylori, in the development of extragastrointestinal diseases including Iron deficiency anemia.

The present study is the first of its kind in Bangladesh where we have seen association between Helicobacter pylori infection and iron deficiency anaemia in adult. Our study has revealed $68.45 \%$ of patients were positive for $H$. pylori who underwent endoscopic biopsy and rapid urease test. This is similar to previous study conducted in Karachi, Pakistan. ${ }^{40}$ In Faisalabad, India $92 \%$ of duodenal ulcer patients found $\mathrm{H}$. pylori positive by rapid urease test. ${ }^{41}$ Previous study conducted in Korean Children where only $23.6 \%$ of patients are positive for $H$. pylori by rapid urease test. ${ }^{42}$ This variation may be due to different prevalence of $H$. pylori in developed and developing countries, and change of prevalence with age.

In our study has found significant low mean serum ferritin level $(\mathrm{P}<.001)$ in H. pylori infected patients. This result is consistent with most of previous data concerning the effect of $H$. pylori infection on iron metabolism. Most previous study had found significant inverse relationship between serum ferritin and $H$. pylori infection. Low serum ferritin level were found in $H$. pylori infected patients in Pakistan ${ }^{40}$, China ${ }^{43}$, Korea $^{44,45}$, German $^{27}$, Denmark ${ }^{23}$, Australia ${ }^{46}$, America ${ }^{47}$ and Alaska ${ }^{48}$. There was no significant differences of serum ferritin level according to $H$. pylori status found in New Zealand ${ }^{29}$, and Korea ${ }^{49}$, Iran $^{50}$, Egypt. ${ }^{51}$

In the multiple linear regression model (adjusted for sex, age, residence, income, family member) our study showed, H. pylori was associated with a $29 \%$ decrease of serum ferritin ( $95 \% \mathrm{CI}=4.9$ to $\left.-9.0 ; \mathrm{r}^{2}=0.26\right)$. Previous study in Denmark ${ }^{23}$, Germany ${ }^{27}$, and America ${ }^{47}$, in the multiple linear regression model $H$. Pylori were associated with a $40 \%, 17 \%$ and $40 \%$ decrease of serum ferritin respectively.

This study has also revealed a significant $(<.001)$ lower value of mean MCV and $\mathrm{MCH}$ in $H$. pylori positive patients. This was similar to that in China ${ }^{43}$, $\mathrm{Korea}^{42}$, and Egypt ${ }^{51}$. These findings did not correlate with that of Pakistan where there was no difference in MCV according to $H$. pylori status. ${ }^{40}$

Regarding Hemoglobin value, our study has showed no significant $(>.05)$ different in haemoglobin level according to $H$. pylori status. This is similar to study in Denmark ${ }^{23}$, Germany ${ }^{27}$, and USA ${ }^{47}$ Low haemoglobin values were found in $H$. pylori infected patient in Pakistan $^{40}$, China ${ }^{43}$ and Egypt. ${ }^{51}$ Though there was no significant low haemoglobin level in our study but mean haemoglobin level was low in $H$. pylori positive patients.

Our study has showed significant low level of serum ferritin, $\mathrm{MCV}, \mathrm{MCH}$ in H. pylori infected patients but haemoglobin value is not significantly decrease. According to literature serum ferritin relates to mobilizable iron stores of the body and can be used as a marker for iron stores. ${ }^{23}$ Haemoglobin levels are maintained within normal range until the body iron stores are exhausted. ${ }^{36}$ Thus haemoglobin levels could be within normal ranges with very low / absent iron stores. ${ }^{23,36}$

\section{Conclusion:}

After exclusion of the most of the possible causes of iron deficiency or iron deficiency anemia by clinical and investigational evaluation our study was able to show that $H$. pylori infection was significantly associated with decrease in serum ferritin, $\mathrm{MCV}, \mathrm{MCH}$. Though in our study, H. pylori were not significantly associated with iron deficiency anemia, it was significantly associated 
with iron deficiency. Based on the above findings, $H$. pylori infection may be sought for and treated in patients with unexplained iron deficiency anemia. Further study with larger sample size may be carried out to establish H. pylori infection as a communicable cause of iron deficiency or iron deficiency anemia next to helminthiasis.

\section{Conflict of Interest: None}

\section{References:}

1. William D. Chey, M.D. Benjamin C.Y. Wong, M.D. and the Practice Parameters Committee of the American College of Gastroenterology. American College of Gastroenterology Guideline on the Management of Helicobacter pylori Infection. Am J Gastroenterol 2007; 102: 1808-25.

2. Taylor, D. N., and J. Parsonnet. Epidemiology and natural history of $H$. pylori infections, In M.J. Blaser, P. F Smith, J. Ravdin, H. Greenberg, and R.L. Guerrant (ed.), Infections of the gastrointestinal tract. Raven Press, New York, N. Y 1995; 551-64.

3. Perez-Perez G I, Rothenbacher D and Brenner $\mathrm{H}$. Epidemiology of Helicobacter pylori infection. Helicobacter 2004; 9: 1-6.

4. Mahalanabish D, Rahaman M M, Sarker S A, Bardhan P K. Helicobacter pylori infection in young Bangladesh Prevalence, socioeconomic and nutritional aspect. Int $\mathrm{J}$ Epidemiol 1996; 25: 894-98.

5. Chiarini A, Cala C, Bonura C, Gullo A, Giuliana G, Peralta S, et al. Prevalence of virulence-associated genotypes of Helicobacter pylori and correlation with severity of gastric pathology in patients from western sicily, Italy. Eur J Clin Microbiol Infect Dis 2009; 28: 437-46.

6. Blaser MJ. Ecology of Helicobacter pylori in the human stomach. J Clin Invest. 1997; 100: 759-62.

7. EUROGAST study Group. Epidemiology of, and risk factors for, Helicobacter pylori infection among 3194 asymptomatic subjects in 17 population. Gut 1993; 34: 1672-76.

8. Warburton VJ, Everett S, Mapstone NP, Axon ATR, Hawkey P, Dixon MF. Clinical and histological associations of cagA and vacA genotypes in Helicobacter pylori gastritis. J Clin Pathol 1998; 51: 55-61.

9. Pounder RE. The prevalence of Helicobacter pylori in different countries. Aliment Pharmacol. Ther 1995; 9: 33-40.

10. Ahmed MM, Rahman M, Rumi AK, Islam S, Huq F, Chowdhury MF et al. Prevalence of Helicobacter pylori in asymptomatic population- a pilot serological study. Bangladesh Journal of Epidemiology 1997; 7:251-54.
11. Dunn BE, Cohen H, Blaser MJ: Helicobacter pylori. Clin Microbiol Rev 2006; 19: 449-90.

12. Dunn BE, Cohen H, Blaser MJ. Helicobacter pylori. Clin. Microbiol. Rev. 1997; 10: 720-41.

13. Zhuang XQ, Lin SR. Study on the relationship between Helicobactr pylori and gastric cancer. Shijie Huaren XiaoHuaZazhi 2000; 8: 206-07.

14. Malfertheiner P, Megraud F, O'Morain C, Bazzoli F, ElOmar E. the European Helicobacter Study Group (EHSG). Current concepts in the management of Helicobacter pylori infection: the Maastricht III Consensus Report. Gut 2007; 56: $772-81$.

15. Malfertheiner P, Megraud F, O'Morain C, Hungin APS, Jones R. The European Helicobacter Study Group (EHSG). Current concepts in the management of Helicobacter pylori infection:the Maastricht II-2000 Consensus Report. Aliment Pharmacol Ther 2002; 16:167-70.

16. Grahamd. Y. Campylobacter pylori and peptic ulcer disease. Gastroenterology 1989;96: 615-25.

17. Cover $\mathrm{Tl}$ and Blaser MJ. Helicobacter in health and disease. Gastroenterology 2009; 136: 1863-73.

18. Drumm B, Perez-Perez GI, Blaser MJ, Sherman PM. Intrafamilial clustering of Helicobacter pylori infection. $\mathrm{N}$ Engl J Med 1990; 322: 359-63.

19. Idris M, Anisur Rehman. Iron deficiency anemia in moderate to severely anaemic patients. J Ayub Med Coll Abbottabad 2005; 17: 45-47.

20. Ali NS, Zuberi RW. Association of iron deficiency anaemia in children of 1-2 years of age with low birth weight, recurrent diarrhoea or recurrent respiratory tract infectiona myth or fact? J Pak Med Assoc 2003; 53: 133-36.

21. Paracha PI, Hameed A, Simon J, Jamil A, Nawab G. Prevalence of anaemia in semi-urban areas of Peshawar, Pakistan: a challenge for heath professionals policy makers. J Pak Med Assoc 1997; 47:49-53.

22. Lanzkowsky ph. Manual of Pediatric Hematology and Oncology. $3^{\text {rd }}$ Ed. 2000.

23. Milman N, Rosenstock S, Andersen L, Jorgensen T, Bonnevie O. Serum ferritin, hemoglobin, and Helicobacter pylori infection: a seroepidemiologic survey comprising 2794 Danish adults. Gastroenterology 1998; 115: 268-74.

24. Rockey DC. Occult gastrointestinal bleeding. N Engl J Med 1999; 341: 38-46.

25. Ciacci C, Sabbatini F, Cavallaro R, Castiglione F, Di bella S, Iovino P, Palumbo A, Tortora R, Amoruso D, Mazzacca G. Helicobacter pylori impairs iron absorption in infected individuals. Dig Liver Dis 2004; 36: 455-60.

26. Ashorn M, Acid and iron- disturbances related to Helicobacter pylori infection. J Pediatr Gastrointerol Nutr 2004; 38: 137-39. 
27. Berg G, Bode G, Blettner M, Boeing H, Brenner H. Helicobacter pylori infection and serum ferritin: a population-based study among 1806 adults in Germany. Am J Gastroenterol 2001; 96:1014-18.

28. Seo JK, Ko JS, Choi KD. Serum ferritin and Helicobacter pylori infection in children: a sero-epidemiologic study in Korea. J Gastroenterol Hepatol 2002; 17:754-57.

29. Collett JA, Burt MJ, Frampton CM, Yeo KH, Champma TM, Buttimore RC, et al. Seroprevalence of Helicobacter pylori in the adult population of Christchurch; Risk factors and relationship to dyspeptic symtoms and iron studies. $\mathrm{N}$ Z Med J 1999; 112: 292-95.

30. Conrad ME, Umbreit JN. Iron absorption and transport-an update. Am J Hematol 2000; 64: 287-98.

31. Schulz HU, Schurer M, Krupp S, Dammann HG, Timm J, Gessner U. effects of acetylsalicylic acid on ascorbic acid concentrations in plasma, gastric mucosa, gastric juice and urine-a double-blind study in healthy subjects. Int J Clin Pharmacol Ther 2004; 42: 481-87.

32. Capurso G, Ricci R, Panzuto F, Passi S, Di Giulio E, Delle Fave G, Annibale B. Intragastric ascorbic but not uric acid is depleted in relation with the increase $\mathrm{pH}$ in patients with atrophic body gastritis $H$. pylori gastritis. Helicobacter 2003; 8: 300-06

33. Park JH, Kim SY, Kim DW, Lee WG, Rhee KH, Youn HS. Correlation between Helicobacter pylori infection and vitamin $\mathrm{C}$ levels in whole blood, plasma, and gastric juice, and the $\mathrm{pH}$ of gastric juice in Korean children. J Pediatr Gastroenterol Nutr 2003; 37: 53-62.

34. Furuta T, Baba S, Takashima M, Futami H, Arai H, Kajimura M, Hanai H, Kaneko E. Effect of Helicobactor Pylori infection on gastric juice pH. Scand J Gastroenterol 1998; 33: 357-63.

35. Walters GO, Miller FM, Worwood M. Serum ferritin concentration and iron stores in normal subjects. J Clin Pathol 1973; 26: 770-72.

36. Coyne D. Iron indices: what do they really mean? Kidney int Suppl 2006; 13: 4-8

37. Van Doorn LJ, Figueirdo C. Megráud F, Pena S, Midolo P, Queiroz DMDM, et al. Geographic distribution of vacA allelic types of Helicobacter pylori. Gastroenterology 1999; 116: $823-30$
38. van Doorn LJ, Figueiredo C, Sanna R, Pena S, Midolo P, Ng EKW, et al. Expanding allelic diversity of Helicobacter pylori vacA. J. Clin. Microbiol 1998; 36: 2597-2603.

39. Miehlke S, Yu J, Schuppler M, Frings C, Kirsch C, Negraszus $\mathrm{N}$, et al. Helicobacter pylori vacA, iceA, and cagA status and pattern of gastritis in patients with malignant and benign gastroduodenal disease. Am J Gastroenterol 2001; 96: 1008-13.

40. State of the children of the world 2007, UNICEF.

41. Javed M, Amin K, Muhammad D, Hussain A, Mahmood N. Prevalence of Helicobacter pylori. Professional Med 2010; 17: 431-39.

42. Park SJ, Lee $\mathrm{CH}$, Chung KS. Red blood cell indices, serum iron and total iron binding capacity in children with Helicobacter pylori infection. J Korean Paediatr 2000;43:755-62

43. LIN Xi, WU Bin. Chinese journal of child health care 2005;3: 436-39.

44. Seo JK, Ko JS, Choi KD. Serum ferritin and Helicobacter pylori infection in children: a sero-epidemiologic study in Korea. J Gastroenterol Hepatol 2002;17: 754-57.

45. Choe YH, Kim SK, Hong YC. The relation between Helicobacter pylori infection and iron deficiency : a seroprevalence study in 937 pubescent children. Arch Dis Child 2003; 88: 178.

46. Peach HG, Bath NE, Farish SJ. Helicobacter pylori infection : An added stressor on iron status of women in the community. Med J Aust 1998; 169:188-90.

47. Victor M. Cardenas, Zuber D. Muiia, Melchor Ortiz, and David Y. Graham. Iron deficiency and Helicobacter pylori infection in the United States. Am J Epidemiol 2006; 163: 127-34

48. Wainwright RB, The US Arctic Investigations Program: Infectious disease prevention and control research in Alaska. Lancet 1996; 347: 517-20.

49. Choi JW. Does Helicobacter pylori infection relate to iron deficiency anaemia in prepubescent children under 12 years of age? Acta Paediatr 2003; 92:970-72.

50. Zamani A, Yazdi ZY, Bahremand S, Ashagh PA, Dejakam A. Journal of Pakistan Medical Association 2011;61: 658-61.

51. Afifi RA, ALI DK, Shaheen A. A localized case-control study of extra gastric manifestation of Helicobacter pylori infection in children. Indian J Paediatric 2011;78:418-22. 